JPPKMI 2 (2) (2021)
JURNAL PENELITIAN DAN PENGEMBANGAN
KESEHATAN MASYARAKAT INDONESIA
JPPKMI
https://journal.unnes.ac.id/sju/index.php/jppkmi

\title{
Perilaku Penerapan Protokol Kesehatan pada Pegawai KKP Kelas I Soekarno Hatta
}

\author{
Fitriana Kurniawati $^{1} \bowtie$, Akhmad Muttaqin ${ }^{1}$ \\ ${ }^{1}$ Program Studi Kesehatan Masyarakat, Fakultas Ilmu Kesehatan, Universitas Respati Indonesia, Indonesia
}

\begin{abstract}
Info Artikel
Sejarah Artikel:

Diterima Juni 2021

Disetujui Desember 2021

Dipublikasi Desember 2021

Keywords:

Covid19, Health Protocol,

Behavior

$U R L:$

https://iournal.unnes.ac.i d/siu/index.php/ippkmi /article/view/52429

Abstrak

Protokol kesehatan dibentuk dengan tujuan masyarakat tetap dapat beraktivitas secara aman dan tidak membahayakan keamanan atau kesehatan orang lain. Penerapan protokol kesehatan yang baik diperlukan untuk mencegah penularan virus Covid 19. Banyaknya pegawai yang masih terpapar Covid 19 di KKP Kelas I Soekarno Hatta erat kaitannya dengan perilaku pegawai dalam menerapkan protokol kesehatan. Penelitian bertujuan untuk mengetahui faktor-faktor yang berhubungan dengan perilaku penerapan protokol kesehatan pada pegawai KKP Kelas I Soekarno Hatta. Penelitian ini berjenis kuantitatif dengan pendekatan cross sectional. Populasi dalam penelitian ini yaitu seluruh pegawai KKP Kelas I Soekarno Hatta baik berstatus ASN maupun honorer yang ditempatkan di kantor induk berjumlah 154 orang. Sampel diambil dengan metode probability sampling menggunakan teknik simple random sampling, sehingga diperoleh jumlah sampel sebanyak populasi (total sampling). Analisis data menggunakan uji statistik Chi Square. Hasil penelitian menunjukkan adanya hubungan antara jenis kelamin dengan perilaku $(p$ value $=0,008)$, sikap $(p$ value $=0,001)$, dan persepsi $(p$ value $=0,022)$, sedangkan umur $(p$ value $=0,277)$, pedidikan $(p$ value $=0,992)$, pengetahuan $(p$ value $=0,402)$, ketersediaan fasilitas $(p$ value $=0,066)$, dan kebijakan manajemen $(p$ value $=0,331)$, tidak berhubungan dengan perilaku penerapan protokol kesehatan. Penelitian ini berguna untuk mengetahui faktor-faktor apa sajakah yang berhubungan dengan penerapan protokol kesehatan dalam rangka monitoring kepatuhan pegawai KKP Kelas I Soekarno Hatta, dan kepada responden disarankan untuk berperilaku baik dalam menerapkan protokol kesehatan dengan mengembangkan sikap dan persepsi positif serta memperketat penerapan protokol kesehatan saat bekerja untuk mencegah penularan virus Covid 19.
\end{abstract}

\begin{abstract}
Health protocols are established with the aim that people can continue to carry out activities safely and do not endanger the safety or health of others. The implementation of good health protocols is needed to prevent the transmission of the Covid 19 virus. The number of employees who are still exposed to Covid 19 at the Soekarno Hatta Class I KKP is closely related to the behavior of employees in implementing health protocols. This study aims to determine the factors related to the behavior of applying health protocols to Soekarno Hatta Class I KKP employees. This research is quantitative with a cross sectional approach. The population in this study were all employees of the Soekarno Hatta Class I KKP, both ASN and honorary statuses placed in the main office, amounting to 154 people. Samples were taken by probability sampling method using simple random sampling technique, in order to obtain a total sample of the population (total sampling). Data analysis used Chi Square statistical test. The results showed that there was a relationship between gender and behavior $(p$ value $=0.008)$, attitude $(p$ value $=0.001)$, and perception $(p$ value $=0.022)$, while age $(p$ value $=0.277)$, education ( $p$ value $=0.992)$, knowledge ( $p$ value $=0.402)$, availability of facilities ( $p$ value $=0.066)$, and management policies ( $p$ value $=0.331$ ), are not related to the behavior of implementing health protocols. This study is useful to find out what factors are related to the application of health protocols in the context of monitoring the compliance of Soekarno Hatta Class I KKP employees, and respondents are advised to behave well in implementing health protocols by developing positive attitudes and perceptions and tightening the application of health protocols when work to prevent the spread of the Covid 19 virus.
\end{abstract}

Alamat korespondensi:

J1. Bambu Apus 1 No.3, Cipayung,

Jakarta Timur, 13890

E-mail: anafitria27@.gmail.com 


\section{PENDAHULUAN}

Protokol kesehatan adalah aturan dan ketentuan yang perlu diikuti oleh segala pihak agar dapat beraktivitas secara aman pada saat pandemi COVID-19 (Kemenkes, 2020). Protokol kesehatan dibentuk dengan tujuan agar masyarakat tetap dapat beraktivitas secara aman dan tidak membahayakan keamanan atau kesehatan orang lain. Jika masyarakat dapat mengikuti segala aturan yang tertera di dalam protokol kesehatan, maka penularan COVID-19 dapat diminimalisir. Mayarakat harus menjaga produktivitas di tengah pandemi Covid-19 dengan tatanan baru yang disebut new normal. Kehidupan baru atau new normal merupakan suatu tatanan kebiasaan dan perilaku baru yang berbasis pada adaptasi untuk membudayakan perilaku hidup bersih dan sehat dengan cara rutin mencuci tangan pakai sabun, memakai masker saat keluar rumah, serta jaga jarak aman dan menghindari kerumunan.

Bandara Soekarno-Hatta merupakan bandara terbesar dan utama Indonesia. Secara administratif bandara ini terletak di kota Tangerang, Banten dan berjarak sekitar 20 kilometer dari ibukota, DKI Jakarta. Dengan tingginya lalu lintas orang yang ada di Bandara Soekarno Hatta ini baik itu domestik maupun internasional, dan jam operasional di bandara ini adalah 24 jam dapat membuat faktor risiko penyebaran penyakitnya lebih tinggi dibandingkan dengan bandara yang lainnya. Faktor risiko penularan kepada petugas KKP ini akan besar jika perilaku petugas dalam menerapkan protokol kesehatan tidak baik. Perilaku pegawai saat bertugas maupun dalam melakukan aktivitas kehidupan sehari-hari sangatlah penting untuk diberikan perhatian dalam mencegah penularan Covid 19 ini.

Berdasarkan observasi penulis, bahwa selama telah diberlakukannya anjuran pemerintah untuk menerapkan protokol kesehatan 5M, fakta di lapangan masih ada petugas yang melepas masker dan berkerumun saat makan bersama. Hal ini menjadi faktor risiko untuk penularan covid 19 dilingkungan KKP dan dapat berpotensi menjadi klaster di perkantoran bandara. Sebagai bentuk dukungan manajemen bagi pegawai adalah dengan menyediakan fasilitas penerapan protokol kesehatan, dan sebagai bentuk upaya pengendalian di KKP bagi pegawai yang tidak menerapkan protokol kesehatan dengan baik adalah dengan teguran lisan dari pimpinan langsung sebagai efek jera bagi pegawai.

Dari bulan Juni tahun 2020 sampai dengan bulan Maret 2021, jumlah pegawai KKP yang terpapar Covid 19 sebanyak 57 orang dengan kriteria 36 orang sembuh dan 1 orang meninggal dunia. Mengingat banyaknya jumlah pegawai KKP Kelas I Soekarno Hatta yang terpapar COVID-19 yaitu sebesar 37\% dari total jumlah pegawai baik ASN dan honorer walaupun telah dilakukan upaya untuk mendukung penerapan protokol kesehatan dalam rangka pencegahan Covid 19 di KKP Soetta, maka peneliti ingin meneliti tentang faktor-faktor apa sajakah yang berhubungan dengan perilaku petugas KKP Kelas I Soekarno Hatta dalam menerapkan protokol kesehatan.

Penelitian ini bertujuan untuk mengetahui faktor-faktor apa sajakah yang berhubungan dengan perilaku pegawai KKP Kelas I Soekarno Hatta dalam menerapkan protokol kesehatan, yang bermanfaat salah satunya sebagai bahan masukan dalam melakukan monitoring evaluasi terhadap kepatuhan penerapan protokol kesehatan bagi pegawai KKP Kelas I Soekarno Hatta dalam menerapkan protokol kesehatan.

\section{METODE}

Penelitian ini merupakan jenis penelitian deskriptif analitik dengan metode penelitian kuantitatif dan menggunakan desain penelitian Cross Sectional. Untuk setiap variabel terdiri yang dari variabel umur, jenis kelamin, pendidikan, pengetahuan, sikap, persepsi, ketersediaan fasilitas, kebijakan manajemen, dan perilaku pegawai KKP diukur dengan menggunakan kuesioner elektronik (google form).

Populasi dalam penelitian ini adalah seluruh pegawai KKP Kelas I Soekarno Hatta yang terdaftar dan masih aktif bekerja dan 
ditempatkan di kantor induk Bandara Soekarno Hatta tahun 2021 sebanyak 154 orang. Sampel dalam penelitian ini menggunakan total dari populasi.

\section{HASIL DAN PEMBAHASAN}

Tabel 1. Distribusi Perilaku Pegawai

\begin{tabular}{lcc}
\hline Perilaku & Jumlah & Presentase \\
\hline Buruk & 53 & $45.7 \%$ \\
Baik & 63 & $54.3 \%$ \\
Total & 116 & $100 \%$ \\
\hline
\end{tabular}

Hasil penelitian terhadap pegawai KKP diketahui bahwa hampir separuh pegawai berperilaku buruk dalam menerapkan protokol kesehatan (45.7\%) dan separuh lebih $(54,3 \%)$ berperilaku baik. Nilai perilaku buruk ini tercermin dalam beberapa diantaranya yang pertama pertanyaan seberapa sering pegawai mandi dan berganti pakaian setelah bertugas sebelum pulang kerumah, seberapa sering memakai masker medis dilengkapi APD, dan seberapa sering mengganti masker minimal $3 \mathrm{x}$ sehari. Menurut Paper Kampf et.al pada The Journal of Hospital Infection (2020) bahwa virus Corona dapat bertahan dalam permukaan benda berbahan kain atau gaun sekali pakai selama 2 hari dalam suhu ruangan. Bandara merupakan tempat umum yang berisiko tinggi untuk penularan Covid-19 maka perilaku petugas seharusnya lebih ketat dalam menerapkan protokol kesehatan untuk mencegah penularan dari pengguna jasa bandara kepada petugas KKP. Petugas setelah selesai bertugas dianjurkan untuk membersihkan diri dan mandi serta berganti pakaian sebelum nantinya pulang ke rumah untuk bertemu dengan keluarga.
Bandara Soekarno Hatta sebagai bandara besar serta melayani penerbangan internasional dan domestik berdasarkan hasil penelitian ada sebesar $45,7 \%$ pegawainya mempunyai perilaku buruk dalam menerapkan protokol kesehatan. Dibandingkan hasil survei social demografi dampak COVID-19 yang dilakukan oleh Badan Pusat Statistik (BPS,2020) tentang perilaku taat protokol kesehatan masyarakat Indonesia selama masa pandemi, didapatkan hasil sebanyak $80,2 \%$ responden sering/selalu, $14.84 \%$ responden kadang-kadang, dan sebanyak $4,96 \%$ responden jarang atau tidak pernah. Hal ini berarti perilaku masyarakat umum masih ada sebagian yang buruk dalam menerapkan protokol kesehatan.

Dapat diketahui hasil analisis hubungan antara kelompok umur pegawai dengan perilaku penerapan protokol kesehatan, diperoleh data bahwa sebanyak 29 orang (51.8\%) pegawai berumur $<44$ tahun dan 24 orang (40\%) pegawai berumur $\geq 44$ tahun berperilaku buruk. Dari hasil analisis menyatakan bahwa tidak ada perbedaan proporsi perilaku penerapan protokol kesehatan antara pegawai yang berumur $<44$ tahun dengan pegawai yang berumur atau $\geq 44$ tahun atau tidak ada hubungan yang signifikan antara kelompok umur dengan perilaku penerapan protokol kesehatan $(p=0.277)$. Menurut Azwar (2012) umur merupakan salah satu faktor yang menentukan kematangan seseorang dalam berfikir, bertindak maupun belajar. Kematangan dalam berfikir seseorang dapat mempengaruhi baik pengetahuan, sikap, maupun praktek seseorang. Proporsi umur pegawai yang berumur $\geq 44$ tahun lebih rendah untuk berperilaku buruk dikarenakan pada umur ini merupakan masa dewasa yang telah matang sehingga akan siap menerima berbagai

Tabel 2. Hubungan antara Umur dengan Perilaku

\begin{tabular}{|c|c|c|c|c|c|c|c|c|}
\hline \multirow{3}{*}{$\begin{array}{l}\text { Umur } \\
\text { (th) }\end{array}$} & \multicolumn{4}{|c|}{ Perilaku } & \multicolumn{2}{|c|}{ Total } & \multirow{2}{*}{$\begin{array}{l}\text { P- } \\
\text { Value }\end{array}$} & \multirow{2}{*}{$\begin{array}{l}\text { OR } \\
(95 \% \mathrm{CI})\end{array}$} \\
\hline & \multicolumn{2}{|c|}{ Buruk } & \multicolumn{4}{|c|}{ Baik } & & \\
\hline & $\mathrm{n}$ & $\%$ & $\mathrm{n}$ & $\%$ & $\mathrm{n}$ & $\%$ & & \\
\hline$<44$ & 29 & 51.8 & 27 & 48.2 & 56 & 100 & & 1.611 \\
\hline$\geq 44$ & 24 & 40.0 & 36 & 60.0 & 60 & 100 & 0.277 & $(0.772-3.363)$ \\
\hline JML & 53 & 45.7 & 63 & 54.3 & 116 & 100 & & \\
\hline
\end{tabular}


Tabel 3. Hubungan antara Jenis Kelamin dengan Perilaku

\begin{tabular}{|c|c|c|c|c|c|c|c|c|}
\hline \multirow[t]{3}{*}{ Jenis Kelamin } & \multicolumn{4}{|c|}{ Perilaku } & \multicolumn{2}{|c|}{ Total } & \multirow{3}{*}{$\begin{array}{l}\text { P- } \\
\text { Value }\end{array}$} & \multirow{3}{*}{$\begin{array}{l}\text { OR } \\
(95 \% \mathrm{CI})\end{array}$} \\
\hline & \multicolumn{2}{|c|}{ Buruk } & \multicolumn{2}{|c|}{ Baik } & \multirow[b]{2}{*}{$\mathrm{n}$} & \multirow[b]{2}{*}{$\%$} & & \\
\hline & $\mathrm{n}$ & $\%$ & $\mathrm{n}$ & $\%$ & & & & \\
\hline Laki-laki & 22 & 66.7 & 11 & 33.3 & 33 & 100 & 0.008 & 3.355 \\
\hline Perempuan & 31 & 37.3 & 52 & 62.7 & 83 & 100 & & $(1.435-$ \\
\hline Jumlah & 53 & 45.7 & 63 & 54.3 & 116 & 100 & & 7.845) \\
\hline
\end{tabular}

informasi dan mengadopsi perilaku yang dianjurkan. Hasil ini juga sejalan dengan penelitian Erika, 2020 bahwa usia tidak mempengaruhi perilaku pencegahan penularan Covid-19 dengan nilai p: 0,273.

Diperoleh data bahwa ada sebanyak 22 orang $(66.7 \%)$ pegawai laki-laki dan 31 orang (37.3\%) pegawai perempuan berperilaku buruk dalam menerapkan protokol kesehatan. Hasil uji chi square diperoleh nilai $p$ value $=0.008$ dimana $<\alpha(0,05)$ maka dapat disimpulkan ada perbedaan proporsi perilaku penerapan protokol kesehatan antara pegawai yang berjenis kelamin laki-laki dengan pegawai yang berjenis kelamin perempuan atau ada hubungan yang signifikan antara kelompok jenis kelamin dengan perilaku penerapan protokol kesehatan. Diperoleh pula nilai $\mathrm{OR}=3.355$, artinya pegawai yang berjenis kelamin laki-laki mempunyai peluang / kesempatan untuk berperilaku buruk dalam menerapkan protokol kesehatan 3 kali lebih besar dibandingkan pegawai yang berjenis kelamin perempuan. Becker (1974) dalam Notoatmodjo (2012) memperkirakan bahwa Teori Lewin yang menyebutkan bahwa jenis kelamin mempunyai pengaruh terhadap perilaku. Adanya hubungan antara jenis kelamin dengan perilaku penerapan protokol kesehatan karena sesuai dengan kodratnya bahwa laki-laki dan perempuan memiliki perbedaan baik secara biologis maupun dari sifat dan tingkah lakunya. Hasil penelitian ini juga sejalan dengan penelitian Barnas, dkk (2019) yang menyatakan bahwa terdapat hubungan perbedaan antara perilaku mahasiswa laki-laki dengan perempuan dalam memelihara kebersihan lingkungan.

Diperoleh data bahwa ada sebanyak 6 orang (50\%) pegawai berpendidikan rendah dan 47 orang (45.2\%) pegawai berpendidikan tinggi berperilaku buruk dalam menerapkan protokol kesehatan. Hasil uji chi square diperoleh nilai $p$ value $=0.992$ dimana $<\alpha(0,05)$ maka dapat disimpulkan tidak ada perbedaan proporsi perilaku penerapan protokol kesehatan antara pegawai yang berpendidikan menengah dengan pegawai yang berpendidikan tinggi atau tidak ada hubungan yang signifikan antara kelompok pendidikan dengan perilaku penerapan protokol kesehatan. Wawan dan Dewi (2018) menyebutkan bahwa ada salah satu perilaku yang terwujud secara sadar namun merugikan kesehatan. Perilaku sadar yang dijalankan secara sadar atau diketahui tetapi tidak menguntungkan kesehatan terdapat pula di kalangan orang yang berpendidikan atau profesional atau secara umum pada masyarakatmasyarakat yang sudah maju. Namun pada dasarnya pendidikan tidak hanya diperoleh dari bangku sekolah formal saja, tetapi juga diperoleh dari lingkungan keluarga, masyarakat dan dari media lainnya seperti media

Tabel 4. Hubungan antara Pendidikan dengan Perilaku

\begin{tabular}{lllllllll}
\hline Pendidikan & \multicolumn{9}{l}{ Perilaku } & \multicolumn{3}{c}{ Total } & $\begin{array}{l}\text { P- } \\
\text { Value }\end{array}$ & $\begin{array}{l}\text { OR } \\
(95 \% \mathrm{CI})\end{array}$ \\
\cline { 2 - 7 } & \multicolumn{2}{l}{ Buruk } & Baik & & & & & \\
\cline { 2 - 7 } & $\mathrm{n}$ & $\%$ & $\mathrm{n}$ & $\%$ & $\mathrm{n}$ & $\%$ & & \\
\hline Menengah & 6 & 50.0 & 6 & 50.0 & 12 & 100 & 0.992 & 1,213 \\
Tinggi & 47 & 45.2 & 57 & 54,8 & 104 & 100 & & $(0,367-$ \\
Jumlah & 53 & 45.7 & 63 & 54.3 & 116 & 100 & & $4,009)$ \\
\hline
\end{tabular}


Tabel 5. Hubungan antara Pengetahuan dengan Perilaku

\begin{tabular}{|c|c|c|c|c|c|c|c|c|}
\hline \multirow[t]{3}{*}{ Pengetahuan } & \multicolumn{4}{|c|}{ Perilaku } & \multicolumn{2}{|c|}{ Total } & \multirow{3}{*}{$\begin{array}{l}\text { P- } \\
\text { Value }\end{array}$} & \multirow{3}{*}{$\begin{array}{l}\text { OR } \\
(95 \% \mathrm{CI})\end{array}$} \\
\hline & \multicolumn{2}{|c|}{ Buruk } & \multicolumn{4}{|c|}{ Baik } & & \\
\hline & $\mathrm{n}$ & $\%$ & $\mathrm{n}$ & $\%$ & $\mathrm{n}$ & $\%$ & & \\
\hline Cukup & 13 & 38.2 & 21 & 61.8 & 34 & 100 & 0.405 & 0,650 \\
\hline Baik & 40 & 48.8 & 42 & 51.2 & 82 & 100 & & $(0,287-$ \\
\hline Jumlah & 53 & 45.7 & 63 & 54.3 & 116 & 100 & & $1,470)$ \\
\hline
\end{tabular}

elektronik dan media cetak. Hasil penelitian ini juga sejalan dengan penelitian dari Pratama (2021) dengan hasil $p$ value $0,242>$ alpha 0,05 yang berarti tidak ada hubungan antara pendidikan masyarakat kabupaten Temanggung dengan pengetahuan protokol kesehatan

Diperoleh data bahwa ada sebanyak 13 orang $(38.2 \%)$ pegawai berpengetahuan cukup dan 40 orang (48.8\%) pegawai berpengetahuan baik mempunyai perilaku buruk dalam menerapkan protokol kesehatan. Hasil uji chi square diperoleh nilai $p$ value $=0.405$ dimana $<\alpha$ $(0,05)$ maka dapat disimpulkan tidak ada perbedaan proporsi perilaku penerapan protokol kesehatan antara pegawai yang berpengetahuan cukup dengan pegawai yang berpengetahuan baik atau tidak ada hubungan yang signifikan antara kelompok pengetahuan dengan perilaku penerapan protokol kesehatan. Bagi sebagian kecil pegawai yang berpengetahuan cukup terlihat dari hasil jawaban pegawai yang salah dalam mengisi kuesioner dengan beberapa pertanyaan, yaitu tentang menjaga jarak aman maksimal dengan orang lain dan mengenai langkah pencegahan apa yang tepat diterapkan saat berada di kerumunan. Teori Everett M, Rogers, (1993) dalam Mulyana (2011) menyebutkan bahwa orang yang sudah tahu (awarenes) terhadap suatu hal belum tentu dia akan berperilaku yang benar sebelum yang bersangkutan melakukan beberapa tahap sampai pada akhirnya dia mengadopsi hal tersebut dengan tepat. Tidak adanya hubungan antara pengetahuan dengan perilaku pegawai dikarenakan perilaku pengawai dipengaruhi oleh tingkat kesadaran pegawai, dimana diketahui bahwa ada sebagian pegawai yang berpengetahuan baik namun tingkat kesadaran nya yang rendah sehingga berdampak pada perilaku yang buruk. Penelitian ini sejalan dengan yang dilakukan oleh Dewi, K dkk (2021) dengan hasil $p$ value $0,624>$ alpha 0.05 yang berarti tidak ada hubungan antara pengetahuan pegawai perusahaan produsen air minum dalam kemasan di Sulawesi Utara dengan tindakan pencegahan Covid-19.

Diperoleh data bahwa ada sebanyak 27 orang $(67.5 \%)$ pegawai dengan sikap negatif dan 26 orang $(34.2 \%)$ pegawai dengan sikap positif berperilaku buruk dalam menerapkan protokol kesehatan. Dengan demikian proporsi kelompok pegawai yang bersikap negatif lebih tinggi dibandingkan pegawai yang bersikap positif. Hasil uji chi square diperoleh nilai $p$ value $=0.001$ dimana $<\alpha(0,05)$ maka dapat disimpulkan ada perbedaan proporsi perilaku penerapan protokol kesehatan antara pegawai yang bersikap negatif dengan pegawai yang bersikap positif atau ada hubungan yang signifikan antara kelompok sikap pegawai dengan perilaku penerapan protokol kesehatan.

Dari hasil analisis diperoleh pula nilai $\mathrm{OR}=3.994$, artinya pegawai yang mempunyai sikap negatif mempunyai peluang / kesempatan

Tabel 6. Hubungan antara Sikap dengan Perilaku

\begin{tabular}{|c|c|c|c|c|c|c|c|c|}
\hline \multirow[t]{3}{*}{ Sikap } & \multicolumn{4}{|c|}{ Perilaku } & \multicolumn{2}{|c|}{ Total } & \multirow{3}{*}{$\begin{array}{l}\text { P- } \\
\text { Value }\end{array}$} & \multirow{3}{*}{$\begin{array}{l}\text { OR } \\
(95 \% \mathrm{CI})\end{array}$} \\
\hline & \multicolumn{2}{|c|}{ Buruk } & \multicolumn{4}{|c|}{ Baik } & & \\
\hline & $\mathrm{n}$ & $\%$ & $\mathrm{n}$ & $\%$ & $\mathrm{n}$ & $\%$ & & \\
\hline Negatif & 27 & 67.5 & 13 & 32.5 & 40 & 100 & 0.001 & 3,994 \\
\hline Positif & 26 & 34.2 & 50 & 65.8 & 76 & 100 & & $(1,770-$ \\
\hline Jumlah & 53 & 45.7 & 63 & 54.3 & 116 & 100 & & $9,013)$ \\
\hline
\end{tabular}


Tabel 7. Hubungan antara Persepsi dengan Perilaku

\begin{tabular}{|c|c|c|c|c|c|c|c|c|}
\hline \multirow[t]{3}{*}{ Persepsi } & \multicolumn{4}{|c|}{ Perilaku } & \multicolumn{2}{|c|}{ Total } & \multirow{3}{*}{$\begin{array}{l}\text { P- } \\
\text { Value }\end{array}$} & \multirow{3}{*}{$\begin{array}{l}\text { OR } \\
(95 \% \mathrm{CI})\end{array}$} \\
\hline & \multicolumn{2}{|c|}{ Buruk } & \multicolumn{4}{|c|}{ Baik } & & \\
\hline & $\mathrm{n}$ & $\%$ & $\mathrm{n}$ & $\%$ & $\mathrm{n}$ & $\%$ & & \\
\hline Negatif & 28 & 59.6 & 19 & 40.4 & 47 & 100 & 0.022 & 2,594 \\
\hline Positif & 25 & 36.2 & 44 & 63.8 & 69 & 100 & & $(1,211-$ \\
\hline Jumlah & 53 & 45.7 & 63 & 54.3 & 116 & 100 & & $5,556)$ \\
\hline
\end{tabular}

untuk berperilaku buruk dalam menerapkan protokol kesehatan 4 kali lebih besar dibandingkan pegawai yang mempunyai sikap positif. Menurut Wawan dan Dewi (2018) bahwa selain faktor genetik dalam pembentukan sikap dapat pula dari pengalaman pribadi seseorang. Adanya hubungan antara sikap dengan perilaku pegawai sikap dikarenakan sikap merupakan salah satu bentuk respon terhadap suatu objek. Hasil penelitian ini juga sejalan dengan penelitian yang dilakukan oleh Festi Ladyani Mustofa dkk (2021) dalam mengetahui hubungan tingkat pengetahuan dan sikap masyarakat terhadap kepatuhan penerapan 3M dalam rangka pencegahan Covid 19 di Jatinegara Jakarta Timur dengan hasil ada hubungan antara sikap dengan perilaku kepatuhan masyarakat dalam menerapkan $3 \mathrm{M}$ $(\mathrm{p}=0,000)$ dengan sikap negatif $(15,6 \%)$ dan sikap positif $(84,4 \%)$.

Diperoleh data bahwa ada sebanyak 28 orang $(59.6 \%)$ pegawai dengan persepsi negatif dan 25 orang $(36.2 \%)$ pegawai dengan persepsi positif berperilaku buruk dalam menerapkan protokol kesehatan. Dengan demikian proporsi kelompok pegawai dengan persepsi negatif lebih tinggi dibandingkan pegawai dengan persepsi positif. Hasil uji chi square diperoleh nilai $p$ value $=0.022$ dimana $<\alpha(0,05)$ maka dapat disimpulkan ada perbedaan proporsi perilaku penerapan protokol kesehatan antara pegawai yang mempunyai persepsi negatif dengan pegawai yang mempunyai persepsi positif atau ada hubungan yang signifikan antara kelompok persepsi pegawai dengan perilaku penerapan protokol kesehatan. Sesuai dengan Teori Health Belief Model dalam Notoatmodjo (2012) menyatakan bahwa seseorang akan mengambil tindakan yang berhubungan dengan kesehatan berdasarkan persepsi dan kepercayaannya. Adanya hubungan antara persepsi dengan perilaku penerapan protokol kesehatan pada pegawai dikarenakan persepsi merupakan hasil pemikiran dari sikap, dimana akan tercermin dalam perilakunya. Penelitian ini sejalan dengan yang dilakukan oleh Rahmafika, dkk (2020) mengenai analisis faktor yang sangat mempengaruhi kepatuhan terhadap protokol kesehatan saat pandemi Covid-19 pada masyarakat Jawa Timur dengan hasil penelitian bahwa perceived benefits mempunyai nilai $p$ value $0.005<0.05$.

Diperoleh data bahwa ada sebanyak 22 orang $(59.5 \%)$ pegawai dengan tidak ada fasilitas dan 31 orang $(39.2 \%)$ pegawai dengan ketersediaan fasilitas mempunyai perilaku yang buruk. Dengan demikian proporsi kelompok pegawai dengan ketidaktersediaan fasilitas lebih rendah dibandingkan pegawai dengan ketersediaan fasilitas dalam menerapkan protokol kesehatan. Hasil uji chi square diperoleh nilai $p$ value $=0.066$ dimana $<\alpha$

Tabel 8. Hubungan antara Ketersediaan Fasilitas dengan Perilaku

\begin{tabular}{|c|c|c|c|c|c|c|c|c|}
\hline \multirow{3}{*}{$\begin{array}{l}\text { Ketersediaan } \\
\text { Fasilitas }\end{array}$} & \multicolumn{4}{|c|}{ Perilaku } & \multicolumn{2}{|c|}{ Total } & \multirow{3}{*}{$\begin{array}{l}\text { P- } \\
\text { Value }\end{array}$} & \multirow{3}{*}{$\begin{array}{l}\text { OR } \\
(95 \% \mathrm{CI})\end{array}$} \\
\hline & \multicolumn{2}{|c|}{ Buruk } & \multicolumn{4}{|c|}{ Baik } & & \\
\hline & $\mathrm{n}$ & $\%$ & $\mathrm{n}$ & $\%$ & $\mathrm{n}$ & $\%$ & & \\
\hline Tidak Ada & 22 & 59.5 & 15 & 40.5 & 37 & 100 & 0.066 & 2,271 \\
\hline Ada & 31 & 39.2 & 48 & 60.8 & 79 & 100 & & $(1,024-$ \\
\hline Jumlah & 53 & 45.7 & 63 & 54.3 & 116 & 100 & & $5,037)$ \\
\hline
\end{tabular}


Tabel 9. Hubungan antara Kebijakan Manajemen dengan Perilaku

\begin{tabular}{|c|c|c|c|c|c|c|c|c|}
\hline \multirow{3}{*}{$\begin{array}{l}\text { Kebijakan } \\
\text { Manajemen }\end{array}$} & \multicolumn{4}{|c|}{ Perilaku } & \multicolumn{2}{|c|}{ Total } & \multirow{3}{*}{$\begin{array}{l}\text { P- } \\
\text { Value }\end{array}$} & \multirow{3}{*}{$\begin{array}{l}\text { OR } \\
(95 \% \mathrm{CI})\end{array}$} \\
\hline & \multicolumn{2}{|c|}{ Buruk } & \multicolumn{4}{|c|}{ Baik } & & \\
\hline & $\mathrm{n}$ & $\%$ & $\mathrm{n}$ & $\%$ & $\mathrm{n}$ & $\%$ & & \\
\hline Tidak Ada & 25 & 52.1 & 23 & 47.9 & 48 & 100 & 0.331 & 1,553 \\
\hline Ada & 28 & 41.2 & 40 & 58.8 & 68 & 100 & & $(0,738-$ \\
\hline Jumlah & 53 & 45.7 & 63 & 54.3 & 116 & 100 & & $3,268)$ \\
\hline
\end{tabular}

$(0,05)$ maka dapat disimpulkan tidak ada perbedaan proporsi perilaku penerapan protokol kesehatan antara pegawai yang disediakan fasilitas dengan pegawai yang tidak ada fasilitas atau tidak ada hubungan yang signifikan antara kelompok ketersediaan fasilitas dengan perilaku penerapan protokol kesehatan. Bagi pegawai yang berperilaku buruk karena tidak disediakan fasilitas dikarenakan memang pada dasarnya mereka sudah memiliki sikap dan persepsi yang negatif, maka ketika tidak disediakan fasilitas akan semakin mendorong untuk berperilaku negatif. Sedangkan bagi pegawai yang menjawab tersedia fasilitas berperilaku baik karena memang sikap dan persepsi mereka positif dan didukung dengan ketersediaan fasilitas yang mendukung perilaku mereka baik. Hasil ini sejalan dengan penelitian dari Elfrida (2015) yaang menyebutkan bahwa tidak ada hubungan antara ketersediaan fasilitas dengan praktik petugas pengumpul limbah medis di Rumah Sakit Cut Meutia Aceh dengan hasil $p$ value $0.225>$ alpha 0.05

Dapat diketahui hasil analisis hubungan antara kelompok kebijakan manajemen bagi pegawai dengan perilaku penerapan protokol kesehatan, diperoleh data bahwa ada sebanyak 25 orang $(52.1 \%)$ pegawai dengan tidak ada kebijakan manajemen dan 28 orang (41.2\%) pegawai dengan adanya kebijakan manajemen mempunyai perilaku yang buruk. Dengan demikian proporsi kelompok pegawai dengan tidak ada kebijakan menajemen lebih rendah dibandingkan pegawai dengan adanya kebijakan manajemen dalam menerapkan protokol kesehatan. Hasil uji chi square diperoleh nilai $p$ value $=0.331$ dimana $<\alpha(0,05)$ maka dapat disimpulkan tidak ada perbedaan proporsi perilaku penerapan protokol kesehatan antara pegawai yang disediakan kebijakan manajemen dengan pegawai yang tidak ada kebijakan manajemen atau tidak ada hubungan yang signifikan antara kelompok kebijakan manajemen dengan perilaku penerapan protokol kesehatan. Tidak adanya hubungan antara kebijakan menajemen dengan perilaku karena kebijakan manajemen tidak mendukung perilaku pegawai dalam menerapkan protokol kesehatan karena sudah tidak lagi diperhatikan oleh pegawai dalam menerapkan protokol kesehatan. Penelitian ini sejalan dengan penelitian dari Karina Zain (2013) yang menyebutkan bahwa tidak ada hubungan antara komitmen manajemen dengan perilaku K3 (Kesehatan Keselamatan Kerja) pegawai di PT Dok dan Perkapalan Surabaya Unit Hull Construction.

\section{PENUTUP}

Kesimpulan dalam penelitian ini yaitu hampir separuh pegawai KKP $(45,7 \%)$ mempunyai perilaku yang buruk dalam menerapkan protokol kesehatan dan berdasarkan hasil analisis bivariate dapat disimpulkan bahwa variabel yang berhubungan dengan perilaku penerapan protokol kesehatan pada pegawai KKP adalah jenis kelamin, sikap , dan persepsi sedangkan variabel yang tidak berhubungan dengan perilaku penerapan protokol kesehatan yaitu umur, tingkat pendidikan, pengetahuan, ketersediaan fasilitas, dan kebijakan manajemen.

Kepada pegawai diharapkan dapat memperbaiki perilaku yang buruk dengan mengembangkan sikap dan persepsi yang positif dan menerapkan perilaku hidup bersih sehat dalam menerapkan protokol kesehatan untuk mencegah penularan Covid-19. Kepada KKP Kelas I Soekarno Hatta diharapkan melakukan 
monitoring dan evaluasi secara rutin terhadap para pegawai nya terkait kepatuhan dalam menerapkan protokol kesehatan dan lebih memperhatikan ketersediaan fasilitas penerapan protokol kesehatan pegawai.

\section{DAFTAR PUSTAKA}

Azwar, S. 2012. Penyusunan Skala Psikologi Edisi II. Dewi K. 2021. Hubungan antara Penegtahuan dan Sikap dengan Tindakan Pencegahan Penyebaran Covid 19 pada Perusahaan Produsen Air Minum dalam Kemasan.Universitas Sam Ratulangi Manado.

Elfrida Santy Purba. 2015. Hubungan Pengetahuan, Sikap dan Ketersediaan Fasilitas dengan Praktik Petugas Pengumpul Limbah Medis di RSU Cut Meutia Aceh Utara.

Erika Untari Dewi. 2020. Faktor-faktor yang Mempengaruhi Perilaku Masyarakat dalam Pencegahan Penularan Covid-19.

Fadilla E.Pratama. 2021. Hubungan Karakteristik Sosiodemografi Individu dengan Pengetahuan Tentang Protokol Kesehatan dalam Upaya
Pencegahan Penularan Covid 19 di Kabupaten Temanggung.

Festi Ladyani. 2020. Hubungan Tingkat Pengetahuan dan Sikap Masyarakat Terhadap Kepatuhan Penerapan 3M dalam Rangka Pencegahan Covid19 di RT 11 RW 12 Jatinegara Jakarta Timur.

Karina Zain. 2013. Hubungan antara Faktor Pembentuk Budaya Keselamatan Kerja dengan Perilaku Kesehatan dan Keselamatan Kerja di PT DOK dan Perkapalan Surabaya Unit Hull Construction.

Mulyana, Deddy. 2011. Ilmu Komunikasi Suatu Pengantar.

Notoatmodjo,S. 2012. Promosi Kesehatan dan Perilaku Kesehatan.

Rahmafika. 2020. Analisis Faktor yang Mempengaruhi Kepatuhan Terhadap Protokol Kesehatan Saat Pandemi Covid-19 pada Masyarakat Jawa Timur.

Syarif Barnas. 2019. Perbedaan Gender dalam Pengetahuan, Sikap, dan Perilaku Mahasiswa Pendidikan Fisika.

Wawan,A.,Dewi M. 2018. Teori \& Pengukuran Pengetahuan, Sikap, dan Perilaku Manusia. 